\title{
CHARACTERIZATION AND PROCESSING OF FRICTION STIR WELDING ON COPPER WELDS
}

\author{
Sriramula Sai kumar ${ }^{1}$, P. Satish Kumar ${ }^{2}$ \\ ${ }^{1} M$-Tech (AMS) Student, Department of Mechanical Engineering, SR Engineering College, Telangana, India \\ ${ }^{2}$ Associate Professor, Department of Mechanical Engineering, SR Engineering College, Telangana, India
}

\begin{abstract}
FSW(Friction Stir Welding) is a welding technology will be a part of different metals with sensible properties. During this paper, $f_{s w}$ attachment b/n steel, aluminum and copper plates with thicknesses of 3 millimeter was welded. Here we tend to had considered completely different completely different\} materials with different combinations i.e copper and copper, copper and aluminum, aluminum \& stainless steel, stainless steel \& copper. Friction Stir Welding experiments were employed to get the good wieldable properties by maintaining the rpm speeds to 1120 revolutions per minute and attachment speed within the limit of 14$112 \mathrm{~mm} / \mathrm{min}$ and here we can adjust the pin profile of the location respect to the line butt. Micro struc analysis can be done for examine the parent and the welded material. Cutting and sectioning of the welded pieces for metallographic analysis of the planes which are perpendicular for the attachment and the travelling direction \& which is parallel to the friction welding was done. Here the mechanical properties of welding which was were determined by employing the same standard micro hardness and also tensile hardness testing and finding the maximum elongation of the metals to the properties of $f$ sw. From experimental fsw process it can be found the pin profile and also the rotational speed, feed is an important in manufacturing of free welds in fsw of aluminum, copper and steel.
\end{abstract}

Key Words: FSW, Aluminum, copper, stainless steel.

\section{INTRODUCTION}

Friction stir process (FSP) is employed to remodel a heterogeneous microstructure to a lot of solid, refined microstructure. There are many attainable methods offered which may be applied to a spread of material shapes and sizes. In several cases, the re-processed areas have superior strength \& formability than parent material, e.g. aluminum, copper, stainless-steel castings are often processed to consolidate voids, or extrusions are often improved in extremely stressed areas. Together with super plastic forming, FSP offers the potential to make complex-shaped components at higher strain rates and in section thicknesses impracticable victimization standard super plastic process.

Friction stir process could be a methodology of adjusting the properties. This deformation is made by forcibly inserting a non-consumable tool into the work piece, and revolving the tool in a very stirring motion because it is pushed laterally through the work piece. The precursor of this system, friction stir welding, is employed to affix multiple pieces of metal while not making the warmth affected zone typical of fusion welding..

\subsection{APPLICATIONS:}

Because of the potential of benefits over arc welding in some applications related to this processes, FSW has received interest from several areas of business operating with aluminium. The benefits embrace the power to provide long lengths of welds in aluminium without any melting of the base material. This provides necessary metallurgic benefits in comparison to traditional arc fastening. Melting of the base material doesn't occur with FSW and this eliminates the chance of natural action cracking that is usually a haul once arc fastening some aluminium alloys. Alternative benefits might include: low distortion related to lower heating throughout the fastening process; elimination of consistence issues that are difficult once arc fastening performed with a -butt preparation, the absence of fastening consumables like shielding gas or filler material.

\subsection{Process}

In friction stir process (FSP), a rotating tool is employed with a pin and a shoulder to one piece of material to form specific property improvement, like rising the material's toughness or flexibility, in a specific area within the fine grain of a second material with properties that improve the primary. The Friction developed in between tool and the work items ends up in localized heating that softens and plasticizes the work piece. A volume of processed material is created by the movement which is formed in the materials from the starting point of pin to rear point of the pin. Throughout this method, material will undergo intense of plastic elongation deformation and these ends up in important grain refinement. FSP changes physical properties while not dynamical physical state that helps engineers produce things with high-strain-rate super plasticity. The base material rising properties of the primary material, whereas mix with the second material. This causes for the base material's properties. This permits for a range of materials to be altered to be modified for things that will need different troublesome to acquire conditions. The 
methods branches off of friction stir attachment (FSW) that uses a similar process to weld 2 items of various materials along while not heating, melting, or having to vary the materials' physical state..

\section{WORKING PRINCIPLE}

Friction Stir attachment is turning into a very important joining method as a result of welding makes best quality wildings for variety of metals as when it is compared to traditional attachment methods. Friction Stir Welding method is a un-consumable attachment method by which tool is employed for getting the resistance temperature in between tool, and also work piece which shown. This process helps the tool for the movement on the joint of two metals line. As this process done the result a plasticized metal was reworked from vanguard of tool to facet. Later, the welding produces a good quality of joint in between 2 plates by interpretation movement of the work piece at the side of applied pressure of the tool

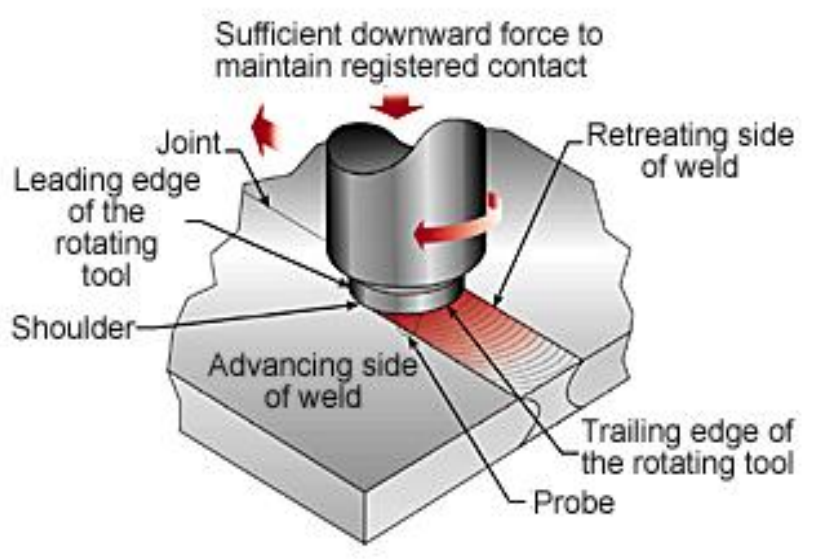

Operating principle of friction stir welding process

\section{EFFECT OF TOOL PIN PROFILE}

The main function of un- expendable rpm of tool pin is to stir the and to make the metal to plasticized metal and to move constant it to own required joint of the plates. Here the Pin and its profile play a vital role in the process of material flow, and this successively regulates fastening rotations of the Friction Stir fastening method. Pin usually has cylindrical plains, solid tapered, rib and flat surface.

Additionally triangle and square pin profile produces a rhythmical stirring action within the flowing material to the flat. Here the square tool pin profile creates 80 pulses/s, and triangle profile creates 60 pulses/s once the tool which is made will rotate at a speed of $1200 \mathrm{rev}$. there's no such rhythmical action within the limit which is made by tapered, rib and cylindrical pin tool profiles. the upper range of rhythmical action practiced within the stir area of the square tool profile which produces terribly good microstructure also the successively yields are higher strength and also the hardness.
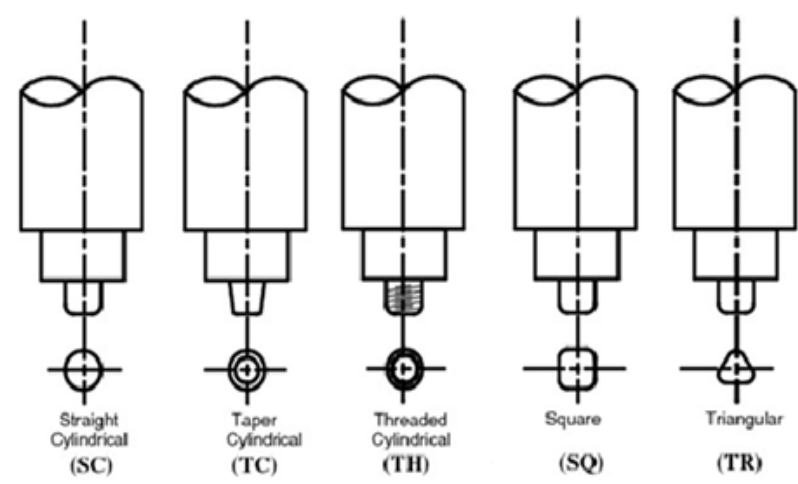

Various pin profiles

\section{FSW PROCESSING, FLOW MECHANISMS} AND TOOL DESIGN

The metal flow and warmth generation within the softened material round the tool ar elementary to the friction stir method. However the material melted during the flow stress of warmth itself and governed the deformation with respect to the temperature. In reality their management lies at the core of virtually all aspects of FSW, as an example, the optimization of method and the machine loading conditions, turning away of the macroscopic demerits, the formation of the microstructure, therefore ensuing weld properties. Most of the fabric within the welding can be extended in between the rotating pin profile on retreating aspect therefore the material that is simply too cold and too gently stressed to deform. In its simplest type, this essential flow mechanism are often illustrated by two-dimensional simulations portraying streamlines spherical the rotating tool is placed during the process of steady flow of metal welding process. The streamlines of the cylindrical tool is generally redacted to procedure fluid dynamics. As a result longitudinal welding seam can be created behind the fringe of tool here the 2 flows are close to each other. In future modeling studies can be investigated however the $2 \mathrm{D}$ flow of the material is hot and bothered. Here the addition tool profile options like flats, flutes are the changes within the contact of area to the conditions in between tool and piece, from the protruding to slippy at lower surface shear stress can be obtained. Foretold stream lines with spherical a fluted profile tool. The complete protruding can generates the dead metal area around tool which is made for the process of welding. Here the flow of metal interacts closely to tool options once slippy takes place during the process. Here another characteristic of the method - a line at first perpendicular to the fastening is swept into the direction of fastening a bulge within the the tool - can be seen. several experiments of fsw have confirmed the behavior of metals. a technique of quantifying the blending result of the tool is that the quantitative relation of swept volume of the plates to volume of the pin. 


\section{H13CHEMICAL COMPOSITION Tool Steels}

\begin{tabular}{|l|l|l|}
\hline Element & Min. (Weight) & Max. ( Weight) \\
\hline Carbon & 0.372 & 0.421 \\
\hline Phosphorus & 00 & 0.025 \\
\hline Sulphur & 00 & 0.0051 \\
\hline Silicon & 0.800 & 1.200 \\
\hline Chromium & 5.000 & 5.500 \\
\hline Vanadium & 0.800 & 1.200 \\
\hline Molybdenum & 1.200 & 1.750 \\
\hline
\end{tabular}

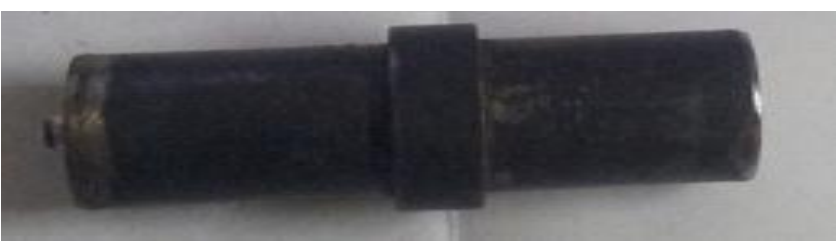

Taper Tool used for FSW

\section{EXPERIMENTAL PROCEDURE}

The experimental study of FSW includes the butt joining of $3 \mathrm{~mm}$ thickness of pure aluminum, copper, stainless-steel plates. The welding methodology is assigned on a vertical milling machine. Tool is hold in tool arbor as shown. Special attachment jigs and fixtures are designed to hold two metal plates of $200 * 60 * 3 * \mathrm{~mm}$ thickness as shown. Table shows the mixtures of the tool movement speed (RPM), welding speed $(\mathrm{mm} / \mathrm{min})$ and tool pure mathematics the diameter of tool pin (Ds/Dp). These mixtures are chosen supported the literature survey and so the aptitude of the milling machine used for the experimental study. The schematic diagrams of tools employed during this methodology are shown.

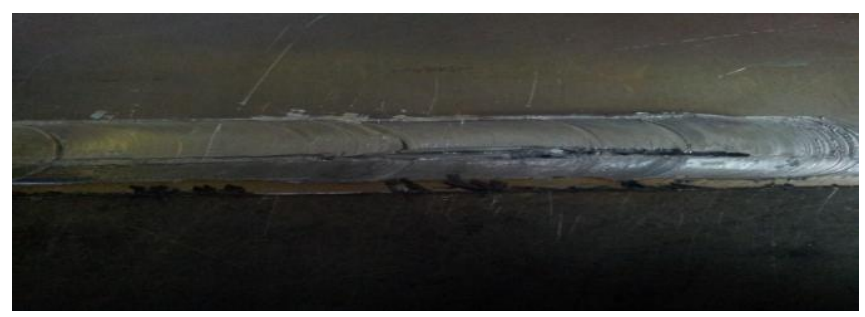

showing welding of aluminum with stainless steel

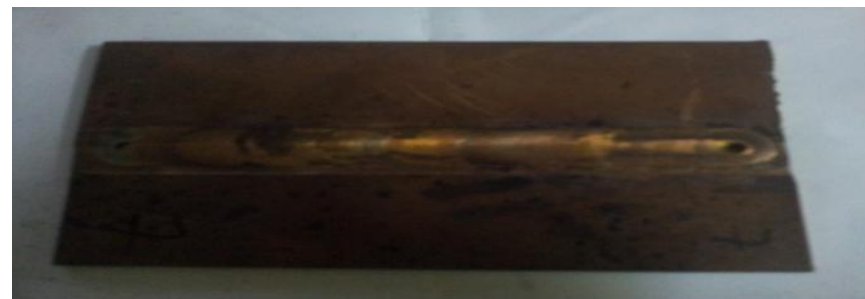

showing total plate after the process of welding

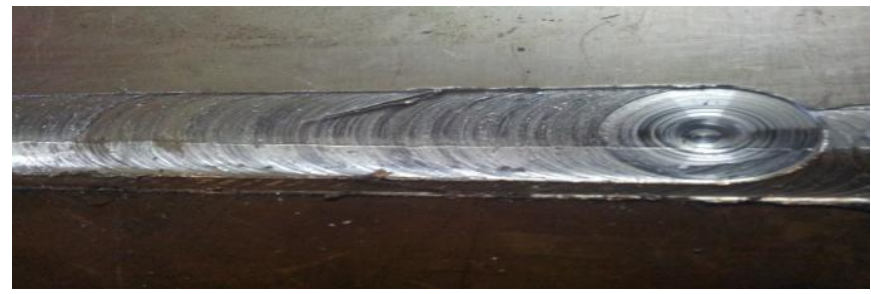

showing welded plates of copper with aluminum

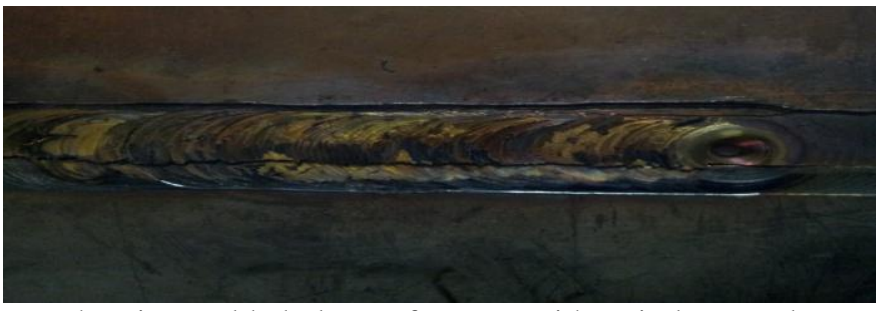

showing welded plates of copper with stain less steel

MECHANICAL PROPERTIES OF PARENTAL META

\begin{tabular}{|l|l|l|l|l|}
\hline MATERIAL & $\begin{array}{l}\text { Y.S } \\
(\text { MPA })\end{array}$ & $\begin{array}{l}\text { U.T.S } \\
(\text { MA) }\end{array}$ & ELONGATION & $\begin{array}{l}\text { WELD } \\
\text { ING } \\
\text { SPEED } \\
(\mathrm{mm} / \mathrm{m} \\
\mathrm{m})\end{array}$ \\
\hline Pure copper & 70 & 224 & 13 & 49 \\
\hline Aluminum & 89 & 115 & 15 & 40 \\
\hline Steel & 207 & 515 & 10 & 10 \\
\hline
\end{tabular}

WELDING IS DONE TO THE MATERIALS WITH FOLLOWING COMPARISIONS

\begin{tabular}{|l|}
\hline Copper + copper \\
\hline Copper + stainless steel \\
\hline Copper + aluminium \\
\hline Aluminium + stainless steel \\
\hline Aluminium + aluminium \\
\hline Stainless steel + stainless steel \\
\hline
\end{tabular}

TABLE SHOWING MATERIALS WELDED WITH FEED /R.P.M/METALS/RESULT

\begin{tabular}{|l|l|l|l|l|}
\hline $\begin{array}{l}\text { Weld } \\
\text { no }\end{array}$ & Combination & R.P.M & FEED & $\begin{array}{l}\text { WELD } \\
\text { QUALITY }\end{array}$ \\
\hline 1 & $\begin{array}{l}\text { Copper + } \\
\text { copper }\end{array}$ & 1120 & 20 & Good \\
\hline 2 & $\begin{array}{l}\text { Copper + } \\
\text { stainless steel }\end{array}$ & 1120 & 20 & Not welded \\
\hline 3 & $\begin{array}{l}\text { Copper + } \\
\text { aluminium }\end{array}$ & 1120 & 20 & $\begin{array}{l}\text { Partially } \\
\text { welded }\end{array}$ \\
\hline 4 & $\begin{array}{l}\text { Aluminium + } \\
\text { stainless steel }\end{array}$ & 1120 & 20 & $\begin{array}{l}\text { Partially } \\
\text { welded }\end{array}$ \\
\hline 5 & $\begin{array}{l}\text { Aluminium + } \\
\text { aluminium }\end{array}$ & 1120 & 20 & Best weld \\
\hline 6 & $\begin{array}{l}\text { Stainless } \\
\text { steel } \\
\text { +stainless } \\
\text { steel }\end{array}$ & 1120 & 20 & Not welded \\
\hline
\end{tabular}

\section{MICRO STRUCTUREOF STEEL}

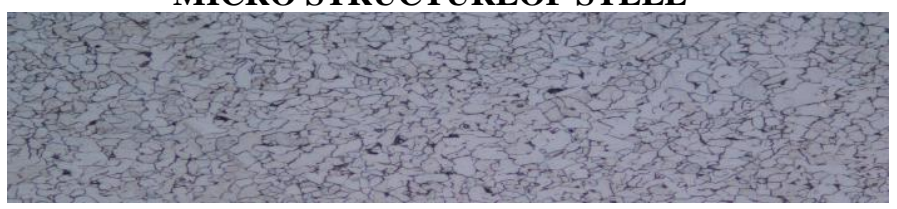

MICRO STRUCTUREOF COPPER

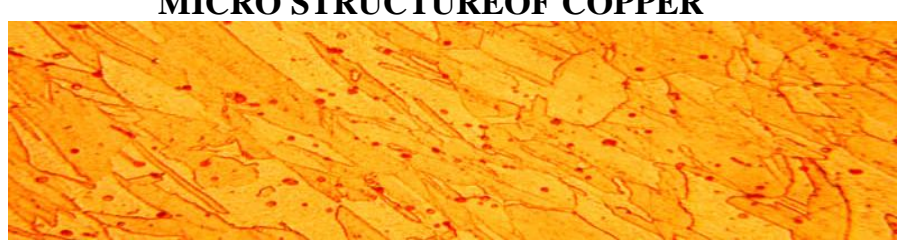


MICRO STRUCTUREOF ALUMINIUM

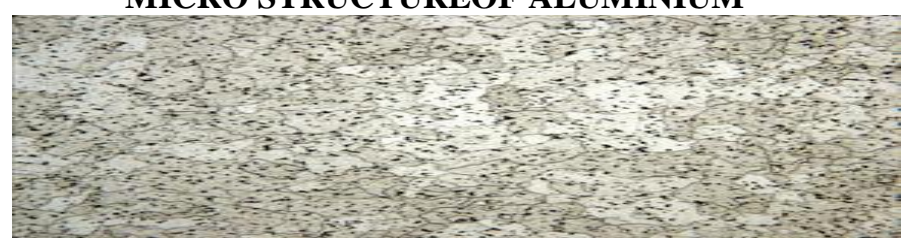

\section{RESULTS AND DISCUSSION:}

[1]. Copper, Aluminum is the best metal for friction stir welding process it gives better results when compared with different rpm and feed and as we increase the rpm the welding output is getting better.

[2]. Tool profile used here is tapper of $2 \times 5 \mathrm{~mm}$

[3]. Strength of tool made is 60 material used is H13

\subsection{RESULT OBTAINED FOR ALUMINIUM} AND COPPER

Welds were obtained in line with the experimental design welds were defect free. The intermixing of metals was conjointly found within the welded samples. throughout the FSW method, the materials were transported from the retiring facet to advancing facet behind the pin wherever the weld was fashioned. Hardness of the copper was larger than the metallic element, and as a result of the pin stirring action the metallic element gets displaced within the weld.

\subsection{RESULT OBTAINED FOR COPPER AND COPPER}

In the process of welding of copper and copper based on the experimental design the welding was defect free. The intermixing of copper and copper had done to the plates which we had chosen. The hardness of copper was high so the tool had made with the specification by with which it can withstand the temperature during the process of welding.

\subsection{RESULT OBTAINED FOR STAINLESS STEEL AND COPPER}

In this process of welding of stainless steel and copper the welding was not done based up the consideration. Here stainless steel and copper are two tough materials which cannot melt and mix-up with each other. If this process gets continuous the tool will get damage.

\subsection{RESULT OBTAINED FOR ALUMINIUM AND ALUMINIUM}

In this welding process the welding output was good and defect free. Here the aluminum and aluminum had melted easily and the material of aluminum had easily mixed up with the other plate of aluminum. Two plates of same metal have been chosen and the hardness of aluminum had equal properties with each other.

\subsection{RESULT OBTAINED FOR ALUMINIUM AND STAINLESS STEEL}

In this process the welding was not properly done due to high strength of stainless steel. The aluminum plate cannot mixed-up with stainless steel. Here the welding quality was poor the quality of weld can be increased if we increase r.p.m of the tool

\section{CONCLUSION}

By observing above results we can conclude that aluminum and aluminum, copper and copper, aluminum and copper can be welded and material can be mixed easily with each other and when stainless steel is used the r.p.m should be high and tool withstanding capability should be higher than 60 for the reason stainless steel has high hardness and it cannot be melted easily.

\section{REFERENCES}

[1]. Arora, H. S.; Mridha, S.; Grewal, H. S.; Singh, H.; Hofmann, D. C.; Mukherjee, S. (2014). "Controlling the length scale and distribution of the ductile phase in metallic glass composites through friction stir processing". Science and Technology of Advanced Materials 15 (3): 035011. doi:10.1088/14686996/15/3/035011. edit

[2]. Sterling, Colin J. (August 2004), "Effects of Friction Stir Processing on the Microstructure and Mechanical Properties of Fusion Welded 304L Stainless Steel" (PDF), Thesis (MSc) (Provo, UT, U.S.A.: Brigham Young University, Department of Mechanical Engineering), retrieved May 16, 2010, "A variation of FSW, called friction stir processing (FSP), uses the same general setup and tools as FSW, but is used to selectively modify the microstructure of materials to enhance specific properties."

[3]. Mahmoud, T. S. (2008), "Effect of friction stir processing on electrical conductivity and corrosion resistance of AA6063-T6 Al alloy" (PDF), Proceedings of the Institution of Mechanical Engineers, Part C: Journal of Mechanical Engineering Science (Professional Engineering Publishing) 222 (7): 11171123, doi:10.1243/09544062JMES847, ISSN 20412983, OCLC 60648821, retrieved May 16, 2010, "During FSP, the metal is exposed to a combination of intense plastic deformation, mixing, and thermal exposure, resulting in a modified microstructure characterized by a very fine and equiaxed grain structure"

[4]. "Friction Stir Processing of Advanced Materials" (PDF), National Transportation Research Center website, Transportation for the 21st Century (Oak Ridge, TN, U.S.A.: Oak Ridge National Laboratory, U.S. Department of Energy), November 2002, archived from the original (PDF) on September 29, 2006, retrieved May 16, 2010, "The tool works heated materials into close contact, causing them to form a solid state joint. No melting of materials occurs; instead, the joint is formed by plastic deformation of the pieces." 